\title{
Comparative effects of dietary inclusion of ginger and turmeric powder on blood profile of Isa Brown pullet chicks
}

${ }^{1 *}$ Kujero, G. O., ${ }^{1}$ Adeyemi, O. A., ${ }^{1}$ Sogunle, O. M., ${ }^{2}$ Sobayo, R. A., ${ }^{1}$ Njoku, C. P. and ${ }^{1}$ Adewole, F. A.

${ }^{\prime}$ Department of Animal Production and Health, Federal University of Agriculture, Abeokuta, Ogun State, Nigeria.

${ }^{2}$ Department of Animal Nutrition, Federal University of Agriculture, Abeokuta, Ogun State, Nigeria.

Abstract

*Corresponding author: kujero

Blood reflects the pathological status of the animals. The use of antimicrobials for treatment of infections has microbiological and clinical evidence of resistant bacteria that might be zoonotic in nature. The effect of dietary inclusion of ginger (Zingiber officinale) and turmeric (Curcuma longa) powder on haematological and serum biochemical indices of pullet chicks was investigated. Five hundred and four Is a Brown day old pullet chicks were divided equally into two groups. Each group was divided into three treatments of four replicates with 21 birds per replicate Birds on treatment 1 (Go) and 4 (To) were fed ration with no inclusion level of ginger or turmeric powder, those on treatments 2 (G1.5) and 5 (T1.5) were on ration containing $1.5 \%$ ginger and turmeric while those placed on treatments 3 (G3) and 6 (T3) were fed diet containing 3\% ginger powder respectively. Birds in $G_{0}$ and $T_{0} ; G_{1.5}$ and $T_{1.5}$; and $G_{3}$ and $T_{3}$ were fed ginger and turmeric powder diets at 0, 1.5 and $3 \%$ inclusion levels respectively for a period of eight weeks. Collected data were arranged in a $2 \times 3$ factorial arrangement while means were separated using New Duncan's Multiple Range Test as contained in the same Statistical Package. One bird per replicate was bled via the jugular vein at the end of the chicks phase to determine the haematological and serum biochemical parameters. Pullet chicks fed 3\% ginger powder ration had higher $(p<0.05)$ heterophils and heterophils:lymphocytes than those on turmeric powder ration. Globulin was significantly $(p<0.05)$ influenced by the interaction between phytobiotic type and inclusion levels. Birds fed $1.5 \%$ dietary ginger recorded the highest value for globulin. Studies on natural growth promoters have recently drawn much attention. However, few researches have considered the early inclusion of these growth promoters in relation to the health response of egg-type chickens. Hence, this study concluded that the inclusion of ginger and turmeric powder in the ration improved the health status of pullet chicks by stimulating their immune response to stress conditions for better performance.

Keywords: Ginger powder, turmeric powder, pullet chicks, haematology, serum biochemistry

\section{Effets comparatifs de l'inclusion alimentaire de gingembre et de poudre de curcuma sur le profil sanguin des poulettes Isa Brown}

\section{Résumé}

Le sang reflète l'état pathologique des animaux. L'utilisation d'antimicrobiens pour le traitement des infections a des preuves microbiologiques et cliniques de bactéries résistantes qui pourraient être de nature zoonotique. L'effet de l'inclusion alimentaire de poudre de gingembre (Zingiber officinale) et de curcuma (Curcuma longa) sur les indices biochimiques hématologiques et sériques des poulettes a été étudié. Cinq cent quatre poussins Isa Brown d'un jour ont été divisés également en deux groupes. Chaque groupe a été divisé en trois 


\section{Comparative effects of dietary inclusion of ginger and turmeric powder on blood profile}

traitements de quatre répétitions avec 21 oiseaux par répétition. 5 (T1.5) étaient sur une ration contenant 1,5\% de gingembre et de curcuma tandis que ceux placés sur les traitements 3 (G3) et 6 (T3) ont été nourris avec un régime contenant 3\% de poudre de gingembre respectivement. Oiseaux en G0 et T0 ; G1.5 et T1.5 ; et G3 et T3 ont été nourris avec des régimes de gingembre et de poudre de curcuma à des niveaux d'inclusion de 0, 1,5 et $3 \%$ respectivement pendant une période de huit semaines. Les données collectées ont été disposées dans un arrangement factoriel $2 \times 3$ tandis que les moyennes ont été séparées à l'aide du test de plage multiple de New Duncan contenu dans le même package statistique. Un oiseau par réplicat a été saigné par la veine jugulaire à la fin de la phase des poussins pour déterminer les paramètres hématologiques et biochimiques sériques. Les poussins nourris avec une ration de poudre de gingembre à $3 \%$ avaient un taux d'hétérophiles et d'hétérophiles:lymphocytes plus élevé $(p<0,05)$ que ceux recevant une ration de poudre de curcuma. La globuline était significativement $(p<0,05)$ influencée par l'interaction entre le type phytobiotique et les niveaux d'inclusion. Les oiseaux nourris à 1,5\% de gingembre alimentaire ont enregistré la valeur la plus élevée pour la globuline. Les études sur les promoteurs de croissance naturels ont récemment attiré beaucoup d'attention. Cependant, peu de recherches ont envisagé l'inclusion précoce de ces promoteurs de croissance en relation avec la réponse sanitaire des poulets de type ouf. Par conséquent, cette étude a conclu que l'inclusion de poudre de gingembre et de curcuma dans la ration améliorait l'état de santé des poussins en stimulant leur réponse immunitaire aux conditions de stress pour de meilleures performances.

Mots clés : Gingembre en poudre, curcuma en poudre, poulettes, hématologie, biochimie sérique

\section{Introduction}

Blood is a specialized fluid responsible for the transport of materials in the body of animals and serves as a pathological reflector of health status of the animals (Menon et al., 2013; Brunel et al., 2018). Those having good blood composition are more likely to exhibit better performance. The examination of blood provides the opportunity to investigate the presence of several metabolites and other components in the body system and it plays a significant role in the physiological, nutritional and pathological status of an organism (Aderemi, 2004). Haematology refers to the study of the numbers and morphology of the cellular elements of the blood and the use of these results in the diagnosis and monitoring of disease (Merck Manual, 2012). Haematological studies are therefore useful in disease prediction as well as discovering the extent of damage caused (Onyeyili et al., 1992) while serum biochemistry involves the chemical analysis of substances which are embedded within the serum such as lipids, proteins, hormones and enzymes. Testing for these various substances provides basic knowledge about the state of the organs and tissues including the metabolic condition of the animal (Williams, 2021). Dietary ginger and turmeric powder may influence haematological components of the blood as they are known to be good sources of antioxidants which possess health promoting organic substances such as gingerone and shogaol of ginger (Fuhrman et al., 2000), and curcumin of turmeric (Chattopadhyay et al., 2004). The use of these medicinal plants as phytobiotics is now increasingly gaining a global attention especially in the aspects of health and nutrition. For instance, the safety of turmeric and its characteristic yellow coloration (curcumin) are endorsed by organizations and researchers (WHO, 
1987; Hallagan et al., 1995). Kehinde et al. (2011) reported that ginger additive was safe up to $3 \%$ level of inclusion in cockerel chick's ration without any adverse effect on haematological constituents. This study therefore focuses on the dietary inclusion levels of ginger and turmeric powder on haematological indices of pullet chicks.

\section{Materials and methods \\ Studylocation}

The study was carried out at Teaching and Research Farm of College of Animal Science and Livestock Production, Federal University of Agriculture, Abeokuta, Ogun State. The location falls within the rainforest vegetation zone of South West Nigeria with mean annual rainfall of 1100 $\mathrm{mm}$ and temperature of $34.7^{\circ} \mathrm{C}$ and relative humidity of $82 \%$. It is in the region of $70 \mathrm{~m}$ above sea level on latitude $7^{\circ} 5^{\prime}$ to $7^{\circ} 8^{\prime} \mathrm{N}$ and longitude $3^{\circ} 11.2^{\prime} \mathrm{E}$ (Google Earth, 2019).

\section{Processing of test ingredients}

Ginger and turmeric rhizomes were obtained from a local market in Lagos State, Nigeria. The rhizomes were washed, cleaned and cut into slices (1-3mm) separately and left to air-dry after which they were pulverized and stored away in an airtight container before they were incorporated into the experimental diets.

\section{Experimental diets}

Chicks diets containing ginger $(\mathrm{G})$ and turmeric (T) powder at $0 \%, 1.5 \%$ and $3 \%$ inclusion levels were fed for a period of 8 weeks and formulated to meet the nutrient requirements of pullet chicks (NRC, 1994) as depicted in Table 1.

Table 1: Composition (\%) of Experimental Chicks Diets

\begin{tabular}{|c|c|c|c|c|c|c|}
\hline \multirow[t]{2}{*}{ Ingredients } & \multicolumn{3}{|c|}{ Ginger (G) powder } & \multicolumn{3}{|c|}{ Turmeric (T) powder } \\
\hline & 0 & 1.5 & 3 & 0 & 1.5 & 3 \\
\hline Maize & 50.00 & 50.00 & 50.00 & 50.00 & 50.00 & 50.00 \\
\hline Wheat offal & 13.05 & 11.55 & 10.05 & 13.05 & 11.55 & 10.05 \\
\hline Soyabean meal & 18.00 & 18.00 & 18.00 & 18.00 & 18.00 & 18.00 \\
\hline Groundnut cake & 14.00 & 14.00 & 14.00 & 14.00 & 14.00 & 14.00 \\
\hline Bone meal & 2.00 & 2.00 & 2.00 & 2.00 & 2.00 & 2.00 \\
\hline Limestone & 2.00 & 2.00 & 2.00 & 2.00 & 2.00 & 2.00 \\
\hline Salt $(\mathrm{NaCl})$ & 0.25 & 0.25 & 0.25 & 0.25 & 0.25 & 0.25 \\
\hline Lysine & 0.25 & 0.25 & 0.25 & 0.25 & 0.25 & 0.25 \\
\hline Methionine & 0.20 & 0.20 & 0.20 & 0.20 & 0.20 & 0.20 \\
\hline *Chicks premix & 0.25 & 0.25 & 0.25 & 0.25 & 0.25 & 0.25 \\
\hline Ginger & 0.00 & 1.50 & 3.00 & 0.00 & 0.00 & 0.00 \\
\hline Turmeric & 0.00 & 0.00 & 0.00 & 0.00 & 1.50 & 3.00 \\
\hline Total & 100.00 & 100.00 & 100.00 & 100.00 & 100.00 & 100.00 \\
\hline \multicolumn{7}{|c|}{ Calculated analysis (\%) } \\
\hline Crude protein & 20.76 & 20.61 & 20.79 & 20.76 & 20.58 & 20.71 \\
\hline Ether extract & 4.52 & 4.50 & 4.45 & 4.52 & 4.50 & 4.45 \\
\hline Crude fibre & 4.36 & 5.74 & 5.83 & 4.36 & 5.58 & 5.49 \\
\hline Ash & 3.34 & 3.44 & 3.47 & 3.34 & 3.54 & 3.60 \\
\hline Calcium & 0.11 & 0.11 & 0.10 & 0.11 & 0.11 & 0.10 \\
\hline Phosphorus & 0.49 & 0.47 & 0.45 & 0.49 & 0.47 & 0.45 \\
\hline Lysine & 0.96 & 0.96 & 0.96 & 0.96 & 0.96 & 0.96 \\
\hline Methionine & 0.42 & 0.42 & 0.42 & 0.42 & 0.42 & 0.42 \\
\hline M.E (kcal/kg) & 2669.71 & 2650.77 & 2632.03 & 2669.71 & 2650.77 & 2632.03 \\
\hline
\end{tabular}

Note: $\mathrm{G}_{0} / \mathrm{T}_{0}=$ Ginger/turmeric powder at $0 \%$ level of inclusion, $\mathrm{G}_{1.5 \%} / \mathrm{T}_{1.5 \%}=$ Ginger /turmeric powder at $1.5 \%$ level of inclusion, $\mathrm{G}_{3} / \mathrm{T}_{3}=$ Ginger/turmeric powder at $3 \%$ level of inclusion; M.E = Metabolisable energy. ${ }^{*}$ Chicks vitamin premix supplied the following vitamins and trace elements per $\mathrm{kg} \operatorname{diet}$ : Vit A 13,000 IU; VitD3 3000IU; VitE, 25 mg; Vitk3 3 mg, VitB1, 1.88 mg Vit B2 3.75 mg; Niacin 31.25 mg; calcium pantothenate $6.25 \mathrm{mg}$; Vit B6 $3.8 \mathrm{mg}$, Vit B12 $0.02 \mathrm{mg}$; Folic acid $0.63 \mathrm{mg}$; Biotin $0.1 \mathrm{mg}$; Mn 60 mg; Fe 60 mg; Zn 50 mg; Cu 5.31 mg; I 0.94 mg; Co 0.25 mg; Se 0.25mg. 


\section{Comparative effects of dietary inclusion of ginger and turmeric powder on blood profile}

\section{Experimental birds and management}

Five hundred and four (504) Isa Brown day old pullet chicks obtained from Chi Farms (Ajanla), Oyo State were used for this study. The chicks were divided equally into two treatment groups. Two hundred and fifty two (252) chicks were fed diets containing ginger powder $(\mathrm{G})$ while the other 252 chicks were placed on ration containing turmeric powder $(\mathrm{T})$. The chicks in each group were further divided into three treatment groups of four replicates per treatment with 21 chicks per replicate. Diets fed to experimental birds in groups $\mathrm{G}_{0}$ and $\mathrm{T}_{0}$ did not include ginger and turmeric powder and served as control diets. The chicks in experimental groups $\mathrm{G}_{1.5}$ and $\mathrm{T}_{1.5}$ were fed diets containing ginger and turmeric powder respectively at $1.5 \%$ inclusion levels while those in experimental groups $\mathrm{G}_{3}$ and $\mathrm{T}_{3}$ were fed diets containing ginger and turmeric powder respectively at $3 \%$ inclusion levels. Fresh feed and water were served ad libitum daily. Routine management and all necessary vaccinations were administered as at when due.

\section{Blood sample collection}

At eight weeks of age, $2 \mathrm{~mL}$ of blood samples were collected via the jugular vein of the neck of the chicks (One bird per replicate) using sterilized syringes, one $\mathrm{mL}$ out of the $2 \mathrm{~mL}$ was immediately emptied into an Ethylene diamine-tetra-acetic acid (EDTA) bottle in order to determine haematological (packed cell volume, haemoglobin, red blood cells (RBC), white blood cells (WBC) and WBC differentials (mean corpuscular volume (MCV), mean corpuscular haemoglobin $(\mathrm{MCH})$ and mean corpuscular haemoglobin concentration (MCHC) ) were analysed. The other one $\mathrm{mL}$ was allocated to a plain sample bottle for assessing biochemical parameters which includes total protein, glucose, triglycerides, total cholesterol, calcium and phosphorus. The blood sample was collected within one minute of capture to ensure that the levels of monitored parameters were not altered by stress induced by pre-sampling handling (Chloupeket al., 2009). Serum total cholesterol, triglycerides and high density lipoprotein (HDL) cholesterol were determined using sigma enzymatic kits according to the methods of Roeschlauet al. (1974), Wahlefeld (1976) and Warnicket al. (1982) respectively while serum low density lipoprotein (LDL) and cholesterol were calculated using Friedewald equation (Friedewaldet al., 1972).

\section{Statistical analysis}

All data collected were subjected to Oneway Analysis of Variance in a $2 \times 3$ factorial arrangement using SAS software while significant $(p<0.05)$ means among variables were separated using New Duncan's Multiple Range Test (Duncan, 1955) as contained in the same statistical package.

$\mathrm{Y}_{\mathrm{ijk}}=+\mathrm{T}_{\mathrm{i}+} \mathrm{L}_{\mathrm{j}}+(\mathrm{TL})_{\mathrm{ij}}+{ }_{\mathrm{ijk}}$

where

$\mathrm{Y}_{\mathrm{ij} \mathrm{k}}=$ observed value of the dependent variable

= population mean

$\mathrm{T}_{\mathrm{i}}=$ effect of $\mathrm{i}^{\text {th }}$ phytobiotic type

$\mathrm{L}_{\mathrm{j}}=$ effect of $\mathrm{j}^{\text {th }}$ phytobiotic level

$(\mathrm{TL})_{\mathrm{ij}}=$ interactive effect of phytobiotic type and level

${ }_{\mathrm{ijk}}=$ error term

\section{Results and discussion \\ Effects of phytobiotic type and inclusion levels on haematological indices of pullet chicks}

The main effects of phytobiotic type and inclusion levels on haematological indices of pullet chicks are illustrated in Table 2 . Although not significant, all haematological parameters followed the same trend with packed cell volume (PCV$37.75 \%)$, haemoglobin $(12.50 \mathrm{~g} / \mathrm{dl})$, red blood cells (RBC - 3.08 $\left.10^{12} / \mathrm{L}\right)$, lymphocytes (64.17\%), MCV (122.76fL) 


\section{Kujero, Adeyemi, Sogunle, Sobayo, Njoku and Adewole}

and $\mathrm{MCHC}(33.11 \mathrm{~g} / \mathrm{dl})$ recording lower values $(p>0.05)$ for chicks fed ginger powder diets while those fed diets containing turmeric powder recorded higher values (PCV - 39.75\%, haemoglobin - $13.26 \mathrm{~g} / \mathrm{dl}$, red blood cells $-3.27 \times 10^{12} / \mathrm{L}$, lymphocytes - 66.42\%, MCV - 171.72fL and $\mathrm{MCHC}-33.36 \mathrm{~g} / \mathrm{dl}$. The comparable mean values of $\mathrm{PCV}$, haemoglobinand $\mathrm{RBC}$ of pullet chicks were in agreement with the findings of Onu et al. (2010); Basavaraj (2011) and Hosseini-Vashan (2012) and Kafi et al. (2017) who reported that supplementation of ginger rhizome powder in broiler chicks' diet did not significantly impact PCV, haemoglobin and RBC. Kehinde et al. (2011) observed that dietary inclusion of ginger powder in cockerel chicks' diets at 1.5, 3.0 and $4.5 \%$ had no significant effect on haematological indices. Conversely, Al-Sultan (2003) and Sugiharto et al. (2011) reported a significant increase in RBC in broiler diets supplemented with turmeric powder at the rate of $10 \mathrm{~g} / \mathrm{kg}$ feed and $600 \mathrm{mg} / \mathrm{kg}$ in the drinking water of broiler chickens respectively. The PCV and haemoglobin levels obtained in this study is close to the normal range of $22.00-35.00 \%$ and $7-13$ $\mathrm{g} / \mathrm{dl}$ for poultry birds as documented by Jain (1993) and Patra et al. (2010), respectively. This may be due to the stimulatory mechanism of the erythropoietic system (Adamson and Longo, 2001). The similarities in the values gotten in this present study indicate that the rations given to the birds are nutritional balanced and contains no deleterious substances that could lead to physiological defects in the birds. Changes in haematological parameters are often used to determine various status of the body and to evaluate stresses due to environmental, nutritional and/or pathological factors (Afolabi et al., $2010)$. Heterophils (32.83\%), heterophils:lymphocytes ratio $(0.52)$, eosinophils $(0.67 \%)$, basophils $(0.92 \%)$, monocytes (1.42\%) and MCH (40.67pg) values among chicks fed ginger powder recorded numerically higher values compared with those fed turmeric powder diets (heterophils - $31.17 \%$, heterophils:lymphocytes ratio - 0.47, eosinophils - $0.33 \%$, basophils $0.75 \%$, monocytes - $1.33 \%$ and $\mathrm{MCH}-40.59 \mathrm{pg}$ ). The inclusion levels of the phytobiotics significantly influenced $(p<0.05)$ heterophils, lymphocytes count and heterophils:lymphocytes ratio. The highest values of heterophils (34.25\%) and heterophils:lymphocytes $(0.55)$ were obtained in birds maintained on $0 \%$ inclusion levels while those on $1.5 \%$ inclusion level recorded the least values of $29.88 \%$.and 0.44 respectively. It is worth noting that the inclusion levels of ginger and turmeric powder were associated with lower heterophils:lymphocytes. This was similar to those reported by HosseiniVashanet al. (2012) and Isroli et al. (2017) who recorded lower $\mathrm{H} / \mathrm{L}$ among broiler chicks fed turmeric powder subjected to heat stress. This suggests that ginger and turmeric may contain some antioxidants which reduced the effects of stress in the pullet chicks. (Lentfer et al., 2015). Lymphocytes count was significantly higher $(\mathrm{p}<0.05)$ among birds placed on $1.5 \%(68.13 \%)$ and $3 \%(65.50 \%)$ inclusion levels compared to the control groups (62.25\%). Lymphocytes play vital role in forming barriers against local infections and may be involved in the formation of antibody (Frandson, 1981). The interactive effects of phytobiotic type and inclusion levels on haematological indices of pullet chicks are presented in Table 3. Phytobiotic type had an effect $(p<0.05)$ on heterophils, lymphocytes and heterophils:lymphocytes ratio. Heterophils:lymphocytes ratio was statistically similar in chicks fed $1.5 \%$ ginger powder $(0.43), 1.5 \%$ turmeric powder $(0.45)$ and $3 \%$ turmeric powder diets $(0.43)$ compared to the rest of the 


\section{Comparative effects of dietary inclusion of ginger and turmeric powder on blood profile}

groups. PCV, Hb, WBC and eosinophils levels in chicks maintained on ginger powder diets were elevated as the inclusion level of ginger powder increases. The lowest values for heterophils $(29.25 \%)$ was obtained among chicks fed 3\% turmeric powder ration while each of those fed diets containing $0 \%$ and $3 \%$ ginger powder had the highest values of $34.50 \%$. Guyton and Hall (2006) affirmed that an elevation in heterophils count in the circulatory system of animals is an indication of bacterial infection. Thus, the reduced heterophils obtained among those chicks may be as a result of the curcuminoids compounds of turmeric powder which performed some antibacterial functions.

The main activity of the WBC and its differentials are to combat infections and defend the body system by engulfing foreign organisms through phagocytosis process as well as transport and distribute antibodies in immune response (Soetan et al., 2013). Thus, low WBC indicates susceptibility to diseases and infections, while those with high counts are able to synthesize antibodies and produce high level of resistance to diseases. White blood cells (WBC) was within the acceptable range for normal chicken $\left(9.20-28.6 \times 10^{9} / \mathrm{L}\right)$ as reported by Albritton (1961), which could mean that the inclusion of ginger and turmeric powder in the rations of the birds had no negative impact on the immune system of the pullets chicks. The lymphocytes values of chick (61.00$69.00 \%$ ) were higher than the reference range for normal chicken (55-60\%) as reported by Patra et al. (2010). The increase in lymphocytes count may be as a result of stimulation of immune response in the pullet chicks due to increased lymphopoiesis as a process of defense mechanism to any form of infection (Patra et al., 2010). These findings were in line with Isroli et al. (2017) who reported that drinking decocted turmeric by broiler chickens resulted in increased lymphocytes count. The in vitro experiment carried out by Lee et al. (2010) revealed an elevation in lymphocytes proliferation (with respect to the control group) in spleen cells after exposure to turmeric powder. The increased quantity of lymphocytes among the phytobiotic groups in the current study may then indicate an enhancement of the immune system of the chicks.

\section{Effects of phytobiotic type and inclusion levels on serum biochemistry of pullet chicks}

The main effects of phytobiotic type and inclusion levels on serum biochemistry of pullet chicks are depicted in Table 4. All serum biochemical indices were not significantly $(p>0.05)$ influenced by phytobiotic type and their inclusion levels. However, similar trends were observed for total protein, globulin and glucose as birds fed diets containing ginger powder recorded lower values compared to those fed turmeric powder. All parameters but albumin and VLDL had lower $(p>0.05)$ values among those fed dietary addition of ginger powder compared to those placed on turmeric powder diets. Total protein and albumin of pullet chicks fed $0 \%$ inclusion level of phytobiotics recorded the lowest ( $>0.05$ ) mean values of $4.53 \mathrm{mg} / \mathrm{dL}$ and $2.48 \mathrm{mg} / \mathrm{dL}$ while the highest values of 4.94 $\mathrm{mg} / \mathrm{dL}$ and $2.63 \mathrm{mg} / \mathrm{dL}$ were obtained for chicks fed $1.5 \%$ inclusion level of phytobiotics respectively. The blood protein is a reflection of protein quality of the experimental diet. Awosanya et al. (1999) posited that blood protein depends on the quality and quantity of dietary protein. It implies that phytobiotics did not impede proper and adequately utilization of protein, since there were no signs of anemia noticed among the birds throughout the chicks phase.

Glucose and total cholesterol increased with increasing inclusion levels while phosphorus and triglycerides followed the 


\section{Kujero, Adeyemi, Sogunle, Sobayo, Njoku and Adewole}

opposite trend. The values obtained for glucose and total cholesterol were lower than the normal range (glucose - 197 to 299 $\mathrm{mg} / \mathrm{dL}$; cholesterol - 129 to $297 \mathrm{mg} / \mathrm{dL}$ ) given by Church et al. (1984). The recorded values for total cholesterol are $87.00 \mathrm{mg} / \mathrm{dL}$ for chicks maintained on $0 \%$ inclusion level, $93.88 \mathrm{mg} / \mathrm{dL}$ for those on $1.5 \%$ inclusion level and $94.38 \mathrm{mg} / \mathrm{dL}$ for those on $3 \%$ inclusion level while triglycerides decreased from 96.75 to 89.63 and then to $87.50 \mathrm{mg} / \mathrm{dL}$. This suggests that compounds in phytobiotics might be able to lower serum triglycerides level. Chicks on $3 \%$ inclusion level recorded the highest value of calcium $(22.58 \mathrm{mg} / \mathrm{dL})$ while those on $1.5 \%$ inclusion level had the lowest calcium value of $20.72 \mathrm{mg} / \mathrm{dL}$. HDL had highest mean values of $55.24 \mathrm{mg} / \mathrm{dL}$ recorded for birds on $1.5 \%$ inclusion levels and the lowest mean of $45.48 \mathrm{mg} / \mathrm{dL}$ was observed in birds fed $0 \%$ inclusion level. Three percent $(3 \%)$ inclusion level of phytobiotics reduced ( $p>0.05)$ VLDL levels compared to other treatment groups.

Interactive effects of phytobiotic type and inclusion levels on serum biochemistry

Table 5 shows the interactive effects of phytobiotic type and inclusion levels on serum biochemistry of pullet chicks. Globulin was significantly $(p<0.05)$ influenced by the interaction between dietary inclusion of phytobiotic type and inclusion levels. Birds fed diet with 1.5\% ginger recorded the highest value for globulin. This result is similar to the findings of Al-Homidan (2005) and Elagib et al. (2012) who reported that supplementation of dietary ginger significantly influenced serum globulin levels in broiler chicks. Venkatesh et al. (2002) reported that the increased serum globulin was an indication that the birds are immunologically strong and that phytobiotics have the capacity to stimulate appetite and digestion as well demonstrate antimicrobial effects. Al-Homidan (2005) fed ginger diets at $2 \%$ inclusion level to chicks for a period of 7 weeks and discovered significant increase in the serum globulin concentration. He suggested that the elevation in serum globulin may be due to the stimulation of the immune system by the ginger diets. Total protein $(4.40,4.78$ and $4.98 \mathrm{~g} / \mathrm{dL})$, albumin $(2.20,2.68$ and $2.78 \mathrm{~g} / \mathrm{dL})$ and HDL (45.8012, 51.98 and $56.33 \mathrm{mg} / \mathrm{dL}$ ) increased numerically with increase in inclusion levels for chicks fed rations containing ginger powder while those on turmeric powder diets did not follow similar trend except for glucose. Total protein obtained in this study falls within the normal range (3.0-4.9 $\mathrm{g} / \mathrm{dL})$ as reported by Church et al. (1984). There were no detrimental clinical signs in the health condition of the pullet chicks in the course of this experiment. Hence, it could be inferred that the total protein range obtained in this study (with respect to the control groups) did not impair adequate utilization of protein as a result of the dietary inclusion of ginger powder. According to Krames (2010), elevated values of serum total protein in ginger treated groups may be due to its nutritional potential effect and the resultant increased body weight gain. In some cases, higher level of serum total protein may accompany the incidence of acute inflammation, dehydration, or cause tissue damage (Murray, 2000). Low Density Lipoprotein (LDL) and High Density Lipoprotein (HDL) are the two major carriers of cholesterol in the blood. Total cholesterol and triglycerides followed no definite pattern except for triglycerides level which decreased numerically for the turmeric powder groups. In this study, the nonsignificance of serum LDL cholesterol, triglycerides and total cholesterol levels is similar to those of Ukoha and Onunkwo (2016) and Esonu (2017) that reported no significant effects of turmeric powder up to $3 \%$ inclusion levels on cholesterol in broiler 


\section{Comparative effects of dietary inclusion of ginger and turmeric powder on blood profile}

chickens. Cholesterol is required by the body to produce hormones, vitamin $\mathrm{D}$ as well as other constituents that partake in food digestion (Adeniyi et al., 2016). The body system can manufacture cholesterol needed to carry out various functions, but the consumption and storage of too much of it may predispose the body to some ill health conditions (Adeniyi et al., 2016). Varbo et al. (2013) and Adeniyi et al. (2016) reported that when the LDL cholesterol level rise above HDL cholesterol level, a disease condition results. This is because it deposits blood cholesterol throughout the body, delivering it as plaque in the arterial walls resulting to a condition known as atherosclerosis (Adeniyi et al., 2016). However, the lower levels of total cholesterol obtained in this work (which is below the range of $129-297 \mathrm{mg} / \mathrm{dL})$ as reported by Church et al. (1984) may be age dependent. Dikmen and Sahan (2007) observed a positive correlation between age and blood cholesterol levels in broiler breeder chickens.

Table 2: Main effects of phytobiotic type and inclusion levels on haematological indices of pullets at

chick phase

\begin{tabular}{|c|c|c|c|c|c|c|c|}
\hline \multirow[t]{2}{*}{ Parameters } & \multicolumn{3}{|c|}{ Phytobiotic type } & \multicolumn{4}{|c|}{ Inclusion levels } \\
\hline & $\begin{array}{l}\text { Ginger } \\
\text { powder }\end{array}$ & $\begin{array}{l}\text { Turmeric } \\
\text { powder }\end{array}$ & $\mathrm{p}$-value & $0 \%$ & $1.5 \%$ & $3 \%$ & p-value \\
\hline $\begin{array}{l}\text { Packed cell volume } \\
(\%)\end{array}$ & $37.75 \pm 0.72$ & $39.75 \pm 1.91$ & 0.3381 & $38.25 \pm 0.94$ & $37.38 \pm 0.92$ & $40.63 \pm 2.78$ & 0.4226 \\
\hline Haemoglobin $(\mathrm{g} / \mathrm{dl})$ & $12.50 \pm 0.22$ & $13.26 \pm 0.64$ & 0.2750 & $12.78 \pm 0.33$ & $12.44 \pm 0.32$ & $13.43 \pm 0.93$ & 0.5052 \\
\hline $\begin{array}{l}\text { Red blood cells } \\
\left(\mathrm{x} 10^{12} / \mathrm{L}\right)\end{array}$ & $3.08 \pm 0.07$ & $3.27 \pm 0.16$ & 0.2979 & $3.13 \pm 0.08$ & $3.04 \pm 0.09$ & $3.36 \pm 0.23$ & 0.2934 \\
\hline $\begin{array}{l}\text { White blood cells } \\
\left(\times 10^{9} / \mathrm{L}\right)\end{array}$ & $12.36 \pm 0.48$ & $12.63 \pm 0.99$ & 0.8042 & $11.43 \pm 0.27$ & $13.75 \pm 1.34$ & $12.31 \pm 0.76$ & 0.2089 \\
\hline Heterophils (\%) & $32.83 \pm 1.11$ & $31.17 \pm 0.69$ & 0.2154 & $34.25 \pm 0.41^{\mathrm{a}}$ & $29.88 \pm 0.77^{\mathrm{b}}$ & $31.88 \pm 1.48^{\mathrm{ab}}$ & 0.0182 \\
\hline Lymphocytes (\%) & $64.17 \pm 1.21$ & $66.42 \pm 0.77$ & 0.1317 & $62.25 \pm 0.56^{\mathrm{b}}$ & $68.13 \pm 0.69^{\mathrm{a}}$ & $65.50 \pm 1.46^{\mathrm{a}}$ & 0.0016 \\
\hline $\begin{array}{l}\text { Heterophils:lympho } \\
\text { cytes }\end{array}$ & $0.52 \pm 0.03$ & $0.47 \pm 0.02$ & 0.1442 & $0.55 \pm 0.01^{\mathrm{a}}$ & $0.44 \pm 0.01^{\mathrm{b}}$ & $0.49 \pm 0.03^{\mathrm{ab}}$ & 0.0072 \\
\hline Eosinophils (\%) & $0.67 \pm 0.22$ & $0.33 \pm 0.14$ & 0.2232 & $0.50 \pm 0.33$ & $0.25 \pm 0.16$ & $0.75 \pm 0.16$ & 0.3308 \\
\hline Basophils (\%) & $0.92 \pm 0.23$ & $0.75 \pm 0.22$ & 0.6030 & $1.25 \pm 0.31$ & $0.88 \pm 0.13$ & $0.38 \pm 0.26$ & 0.0632 \\
\hline Monocytes (\%) & $1.42 \pm 0.34$ & $1.33 \pm 0.22$ & 0.8386 & $1.75 \pm 0.31$ & $0.88 \pm 0.23$ & $1.50 \pm 0.42$ & 0.1809 \\
\hline $\mathrm{MCV}(\mathrm{fL})$ & $122.76 \pm 2.43$ & $171.72 \pm 1.00$ & 0.6958 & $122.45 \pm 1.51$ & $123.48 \pm 3.53$ & $120.79 \pm 1.08$ & 0.7106 \\
\hline $\mathrm{MCH}(\mathrm{pg})$ & $40.67 \pm 0.79$ & $40.59 \pm 0.33$ & 0.9312 & $40.90 \pm 0.48$ & $41.09 \pm 1.18$ & $39.90 \pm 0.09$ & 0.4830 \\
\hline $\mathrm{MCHC}(\mathrm{g} / \mathrm{dl})$ & $33.11 \pm 0.19$ & $33.36 \pm 0.07$ & 0.2376 & $33.40 \pm 0.09$ & $33.26 \pm 0.06$ & $33.04 \pm 0.29$ & 0.3727 \\
\hline
\end{tabular}




\section{Kujero, Adeyemi, Sogunle, Sobayo, Njoku and Adewole}

Table 3: Interactive effects of phytobiotic type and inclusion levels on haematological indices of pullet chicks

\begin{tabular}{|c|c|c|c|c|c|c|c|}
\hline \multirow[t]{2}{*}{ Parameters } & \multicolumn{3}{|c|}{ Ginger powder } & \multicolumn{3}{|c|}{ Turmeric powder } & \multirow[t]{2}{*}{ p-value } \\
\hline & $0 \%$ & $1.5 \%$ & $3 \%$ & $0 \%$ & $1.5 \%$ & $3 \%$ & \\
\hline $\begin{array}{l}\text { Packed cell volume } \\
(\%)\end{array}$ & $36.50 \pm 1.44$ & $37.25 \pm 1.11$ & $39.50 \pm 0.87$ & $40.00 \pm 0.00$ & $37.50 \pm 1.66$ & $41.75 \pm 5.86$ & 0.7132 \\
\hline Haemoglobin $(\mathrm{g} / \mathrm{dl})$ & $12.15 \pm 0.49$ & $12.40 \pm 0.38$ & $12.95 \pm 0.25$ & $13.40 \pm 0.06$ & $12.48 \pm 0.57$ & $13.90 \pm 1.95$ & 0.7100 \\
\hline $\begin{array}{l}\text { Red blood cells } \\
\left(\mathrm{x} 10^{12} / \mathrm{L}\right)\end{array}$ & $3.05 \pm 0.14$ & $2.95 \pm 0.10$ & $3.25 \pm 0.05$ & $3.20 \pm 0.06$ & $3.13 \pm 0.14$ & $3.48 \pm 0.48$ & 0.6376 \\
\hline $\begin{array}{l}\text { White blood cells } \\
\left(\times 10^{9} / \mathrm{L}\right)\end{array}$ & $12.05 \pm 0.26$ & $12.13 \pm 0.88$ & $12.90 \pm 1.23$ & $10.80 \pm 0.06$ & $15.38 \pm 2.42$ & $11.73 \pm 0.97$ & 0.2092 \\
\hline Heterophils (\%) & $34.50 \pm 0.87^{\mathrm{a}}$ & $29.50 \pm 1.44^{b}$ & $34.50 \pm 2.25^{\mathrm{a}}$ & $34.00 \pm 0.00^{\mathrm{a}}$ & $30.25 \pm 0.75^{b}$ & $29.25 \pm 0.75^{b}$ & 0.0083 \\
\hline Lymphocytes (\%) & $61.00 \pm 0.58^{b}$ & $69.00 \pm 0.82^{\mathrm{a}}$ & $62.50 \pm 1.76^{b}$ & $63.50 \pm 0.29^{b}$ & $67.25 \pm 1.03^{\mathrm{a}}$ & $68.50 \pm 0.96^{\mathrm{a}}$ & 0.0001 \\
\hline $\begin{array}{l}\text { Heterophils/Lymph } \\
\text { ocytes }\end{array}$ & $0.57 \pm 0.02^{\mathrm{a}}$ & $0.43 \pm 0.03^{b}$ & $0.56 \pm 0.05^{\mathrm{a}}$ & $0.54 \pm 0.00^{\mathrm{a}}$ & $0.45 \pm 0.01^{\mathrm{b}}$ & $0.43 \pm 0.02^{b}$ & 0.0012 \\
\hline Eosinophils (\%) & $1.00 \pm 0.58$ & $0.25 \pm 0.25$ & $0.75 \pm 0.25$ & $0.00 \pm 0.00$ & $0.25 \pm 0.25$ & $0.75 \pm 0.25$ & 0.2264 \\
\hline Basophils (\%) & $1.50 \pm 0.29$ & $0.75 \pm 0.25$ & $0.50 \pm 0.50$ & $1.00 \pm 0.58$ & $1.00 \pm 0.00$ & $0.25 \pm 0.25$ & 0.2538 \\
\hline Monocytes (\%) & $2.00 \pm 0.58$ & $0.50 \pm 0.29$ & $1.75 \pm 0.63$ & $1.50 \pm 0.29$ & $1.25 \pm 0.25$ & $1.25 \pm 0.63$ & 0.3526 \\
\hline $\mathrm{MCV}(\mathrm{fL})$ & $119.80 \pm 0.92$ & $126.90 \pm 7.07$ & $121.58 \pm 2.22$ & $125.10 \pm 2.25$ & $120.05 \pm 0.45$ & $120.00 \pm 0.32$ & 0.5002 \\
\hline $\mathrm{MCH}(\mathrm{pg})$ & $39.90 \pm 0.28$ & $42.25 \pm 2.35$ & $39.85 \pm 0.15$ & $31.90 \pm 0.58$ & $39.93 \pm 0.14$ & $39.95 \pm 0.13$ & 0.3206 \\
\hline $\mathrm{MCHC}(\mathrm{g} / \mathrm{dl})$ & $33.25 \pm 0.03$ & $33.28 \pm 0.06$ & $32.80 \pm 0.60$ & $33.55 \pm 0.14$ & $33.25 \pm 0.12$ & $33.28 \pm 0.03$ & 0.5170 \\
\hline
\end{tabular}

a, b, Means within the same row with different superscripts differ significantly $(\mathrm{P}>0.05)$.

$\mathrm{MCV}$ - Mean corpuscular volume, $\mathrm{MCH}$ - Mean corpuscular haemoglobin, $\mathrm{MCHC}$ - Mean corpuscular haemoglobin concentration, $\mathrm{fL}$ - femtolitre, pg - pictogram, g/dl - gram per decilitre.

Table 4: Main effects of phytobiotic type and inclusion levels on serum biochemistry of pullet chicks

\begin{tabular}{llllcccc}
\hline Parameters & \multicolumn{3}{c}{ Phytobiotic type } & \multicolumn{5}{c}{ Inclusion levels } \\
\cline { 2 - 7 } & Ginger powder & $\begin{array}{c}\text { Turmeric } \\
\text { powder }\end{array}$ & p-value & $0 \%$ & $1.5 \%$ & $3 \%$ & -value \\
\hline $\begin{array}{l}\text { Total protein } \\
\text { (g/dl) }\end{array}$ & $4.72 \pm 0.13$ & $4.73 \pm 0.15$ & 0.9340 & $4.53 \pm 0.13$ & $4.94 \pm 0.16$ & $4.71 \pm 0.19$ & 0.2300 \\
Albumin (g/dl) & $2.55 \pm 0.16$ & $2.54 \pm 0.15$ & 0.9708 & $2.48 \pm 0.21$ & $2.63 \pm 0.17$ & $2.54 \pm 0.22$ & 0.8665 \\
Globulin (g/dl) & $2.17 \pm 0.07$ & $2.19 \pm 0.09$ & 0.8304 & $2.05 \pm 0.08$ & $2.31 \pm 0.12$ & $2.18 \pm 0.08$ & 0.1669 \\
Glucose (mg/dl) & $11.13 \pm 0.61$ & $11.53 \pm 0.57$ & 0.6388 & $10.20 \pm 0.37$ & $11.63 \pm 0.74$ & $12.15 \pm 0.84$ & 0.1362 \\
Calcium (mg/dl) & $21.07 \pm 1.55$ & $22.58 \pm 1.66$ & 0.5131 & $22.18 \pm 1.20$ & $20.72 \pm 2.14$ & $22.58 \pm 2.46$ & 0.7901 \\
Phosphorus & $17.98 \pm 0.63$ & $18.53 \pm 0.55$ & 0.5211 & $19.35 \pm 0.82$ & $17.93 \pm 0.53$ & $17.50 \pm 0.70$ & 0.1665 \\
(mg/dl) & & & & & & & \\
Total cholesterol & $90.42 \pm 3.86$ & $93.08 \pm 3.47$ & 0.6126 & $87.00 \pm 2.95$ & $93.88 \pm 4.45$ & $94.38 \pm 5.56$ & 0.4387 \\
(mg/dl) & & & & & & & \\
Triglycerides & $89.92 \pm 3.19$ & $92.67 \pm 2.76$ & 0.5211 & $96.75 \pm 4.10$ & $89.63 \pm 2.63$ & $87.50 \pm 3.50$ & 0.1665 \\
(mg/dl) & & & & & & & \\
HDL (mg/dl) & $51.37 \pm 3.45$ & $51.98 \pm 2.71$ & 0.8909 & $45.48 \pm 3.95$ & $55.24 \pm 2.73$ & $54.30 \pm 3.73$ & 0.1199 \\
LDL (mg/dl) & $6.00 \pm 0.53$ & $6.54 \pm 0.48$ & 0.4564 & $5.48 \pm 0.41$ & $6.93 \pm 0.76$ & $6.41 \pm 0.58$ & 0.2457 \\
VLDL (mg/dl) & $123.92 \pm 2.88$ & $119.75 \pm 4.03$ & 0.4098 & $121.25 \pm 4.68$ & $123.75 \pm 4.21$ & $120.50 \pm 4.39$ & 0.8639 \\
\hline
\end{tabular}

HDL - High density lipoprotein, LDL - Low density lipoprotein, VLDL - Very low density lipoprotein.

$\mathrm{MCV}$ - Mean corpuscular volume, $\mathrm{MCH}$ - Mean corpuscular haemoglobin, $\mathrm{MCHC}$ - Mean corpuscular haemoglobin concentration, fL - femtolitre, pg - pictogram, g/dl - gram per dec 


\section{Comparative effects of dietary inclusion of ginger and turmeric powder on blood profile}

Table 5: Interactive effects of phytobiotic type and inclusion levels on serum bi ochemical indices of pullet chicks

\begin{tabular}{llllllll}
\hline Parameters & \multicolumn{5}{c}{ Ginger powder } & \multicolumn{4}{c}{ Turmeric powder } \\
\cline { 2 - 7 } & \multicolumn{1}{c}{$0 \%$} & \multicolumn{1}{c}{$1.5 \%$} & \multicolumn{1}{c}{$3 \%$} & \multicolumn{1}{c}{$0 \%$} & \multicolumn{1}{c}{$1.5 \%$} & \multicolumn{1}{c}{$3 \%$} & p-value \\
\hline Total protein (g/dl) & $4.40 \pm 0.23$ & $4.78 \pm 0.06$ & $4.98 \pm 0.28$ & $4.65 \pm 0.14$ & $5.10 \pm 0.31$ & $4.45 \pm 0.22$ & 0.2254 \\
Albumin (g/dl) & $2.20 \pm 0.28$ & $2.68 \pm 0.15$ & $2.78 \pm 0.35$ & $2.75 \pm 0.26$ & $2.58 \pm 0.33$ & $2.30 \pm 0.23$ & 0.5905 \\
Globulin (g/dl) & $2.20 \pm 0.06^{\mathrm{ab}}$ & $2.10 \pm 0.16^{\mathrm{b}}$ & $2.20 \pm 0.17^{\mathrm{ab}}$ & $1.90 \pm 0.12^{\mathrm{b}}$ & $2.53 \pm 0.09^{\mathrm{a}}$ & $2.15 \pm 0.03^{\mathrm{b}}$ & 0.0321 \\
Glucose (mg/dl) & $9.95 \pm 0.61$ & $12.28 \pm 1.42$ & $11.15 \pm 0.93$ & $10.45 \pm 0.49$ & $10.98 \pm 0.49$ & $13.15 \pm 1.33$ & 0.2285 \\
Calcium (mg/dl) & $22.50 \pm 0.23$ & $17.43 \pm 0.42$ & $23.28 \pm 4.40$ & $21.85 \pm 2.57$ & $24.00 \pm 3.74$ & $21.88 \pm 2.95$ & 0.6623 \\
Phosphorus (mg/dl) & $18.70 \pm 1.67$ & $17.35 \pm 1.00$ & $17.90 \pm 0.60$ & $20.00 \pm 0.23$ & $18.50 \pm 0.29$ & $17.10 \pm 1.35$ & 0.3968 \\
Total cholesterol (mg/dl) & $87.00 \pm 6.35$ & $86.75 \pm 3.64$ & $97.50 \pm 9.24$ & $87.00 \pm 0.58$ & $101.00 \pm 6.72$ & $91.25 \pm 7.25$ & 0.4695 \\
Triglycerides (mg/dl) & $93.50 \pm 8.37$ & $86.75 \pm 4.99$ & $89.50 \pm 3.01$ & $100.00 \pm 1.15$ & $92.50 \pm 1.44$ & $85.50 \pm 6.74$ & 0.3968 \\
HDL (mg/dl) & $45.80 \pm 8.26$ & $51.98 \pm 3.13$ & $56.33 \pm 5.84$ & $45.15 \pm 2.22$ & $58.50 \pm 4.23$ & $52.28 \pm 5.29$ & 0.4075 \\
LDL (mg/dl) & $5.55 \pm 0.55$ & $7.23 \pm 1.37$ & $5.23 \pm 0.40$ & $5.40 \pm 0.69$ & $6.63 \pm 0.85$ & $7.60 \pm 0.70$ & 0.2277 \\
VLDL (mg/dl) & $129.50 \pm 0.87$ & $124.25 \pm 6.64$ & $118.00 \pm 4.92$ & $113.00 \pm 7.51$ & $123.25 \pm 6.21$ & $123.00 \pm 7.85$ & 0.5294 \\
\hline \multicolumn{2}{c}{ ab, Means within the same row with different superscripts differ significantly (p<0.05). } \\
\multicolumn{1}{c}{ HDL - High density lipoprotein, LDL - Low density lipoprotein, VLDL - Very low density lipoprotein. } &
\end{tabular}

\section{Conclusion}

The study implied that dietary inclusion of ginger and turmeric powder did not impact the lipid profile of pullets at chicks phase but improved their health status by stimulating immune response to stress conditions which directly affect good performance.

\section{References}

Adamson, J. W., and Longo, D. L., 2001. Anemia and polycythemia. pp.348354. In:e. Braundwald, A.S. Fauci, D.L. Kasper, S.L. Hauser, D.L, Longo, and J.L. Jameson, eds. Harrison's principles of internal Medicine. $15^{\text {th }}$ edition. McGrawHill, New York, NY.

Adeniyi, P. O., Obatolu, V. A., and Farinde, E. O., 2016. Comparative Evaluation of Cholesterol Content and Storage Quality of Chicken and Quail Eggs. World Journal of Nutrition and Health, Vol. 4, No. 1, 5-9.doi:10.12691/jnh-4-1-2

Aderemi, F. A., 2004. Effects of replacement of wheat bran with cassava root sieviate supplemented or unsupplemented with enzyme on the haematology and serum biochemistry of pullet chicks.
Tropical Journal of Animal Science, 7:147-153.

Afolabi, K. D., Akinsoyinu, A. O., Olajide, R. and Akinleye, S. B. 2010. Haematological parameters of the Nigerian local grower chickens fed varying dietary levels of palm kernel cake. Proceedings of 35th Annual Conference of Nigerian Society for Animal Production. pp.247.

Albritton, A. B. 1961. Standard values in blood. Philadelphia, W. B. Saunders.pp. 19.

Al-Homidan, A. A. 2005. Efficacy of Using Different Sources and Levels of Allium cepa, Allium SativumandZingiberofficinale on Broiler Chicks Performance. Saudi Journal of Biological Sciences, 12: 96-102.

Al-Sultan, S. I., and Gameel, A. A. 2004. Histopathological changes in the livers of broiler chicken supplemented with turmeric (Curcuma longa). International Journal of Poultry Science 3:333 336 . U R L : https://scialert.net/abstract/?doi=ij ps.2004.333.336

Awosanya, B., Joseph, J. R., Apata, D. F., 


\section{Kujero, Adeyemi, Sogunle, Sobayo, Njoku and Adewole}

and Agboola, M. A 1999. Performance, blood chemistry and carcass quality attributes of rabbits fed raw and processed pueraria seed meal. Tropical Journal of Animal Science, 2(2): 89-96.

Basavaraj, M., Nagabhushana, V., Prakash, N., Appannavar, M. M., W a $\mathbf{g}$ m a r e , P a $\mathbf{n} \mathbf{d}$ Mallikarjunappa, S. 2011. Effect of dietary supplementation of Curcuma longa on the biochemical profile and meat characteristics of broiler rabbits under summer stress. Veterinary World, 4 (1): 1518.doi: 10.5455/vetworld.2011.1518

Brunel, H. S. S., Dallago, B. S. L., de Almeida, A. M. B., de Assis, A. Z., Calzada, R. J. B., de Alvarenga, A. B. B., Menezes, A. M., Barbosa, J. P., Lopes, P. R., Gonzalez, F. H. D., McManus, C., Broom, D., Bernal, F. E. M. (2018). Hemato-biochemical profile of meat cattle submitted to different types of pre-loading handling and transport times. I J V S M . $6: 90-96$. https://doi.org/10.1016/j. ijvsm.2018.04.002

Chat topadhyay, I., B iswas, K., B and yop a d hy ay, U. and Banerjee, R. K. 2004. Review Articles: Turmeric and Curcumin: Biological Actions and Medicinal Applications. Current Science, 87 ( 1 ) : 44 53.http://www.ias.ac.in/currsci/jul 102004/44.pdf

Church, J. P., Judd, J. T. Yomg, C. W. Kebay, T. L. and Kim, W. W. 1984. Relationship among dietary constituents and specific serum clinical components of subjects eating self selecting diets. American Journal of Clinical
Nutrition, 40:1338- 1344.

Dikmen, B. Y. and Sahan, U. 2007. Correlations between breeder age, egg cholesterol content, blood cholesterol level and hatchability of broiler breeders. British Poultry Science, 48(1): 98-103. doi: 10.1080/00071660601161412.

Dobrzycki, T., Lalwani, M., Telfer, C., Monteiro, R. and Patient, R. 2020. The roles and controls of GATA factors in blood and cardiac development. IUBMB Life. 72: 39-44. doi: 10.1002/iub.2178.

Duncan, D. B. 1955. Multiple Range and Multiple F tests. Biometrics. 11:142.

Elagib, H. A. A., Nabiela, E. M, Abbass, S. A., Ginawi, T.A. N. 2012. Effect of Natural Spices on Plasma Proteins in Broiler Chicks. Journal of Nutrition and Food Sciences. 2:152. doi:10.4172/21559600.1000152 .

Esonu, B. O., Obionwu, D. C. and Okoli, I. C. 2017.Haematology and serum biochemistry of finisher broilers fed raw and cooked turmeric (Curcuma longa) rhizome. International Journal of Agricultural and Rural Development. 20(1): 2926-2932.

Frandson, R. D. and Whitten, E. H. 1981. Anatomy and physiology of farm animals. $1^{\text {st }}$ edition. Lea and Febiger Publishers, Philadelphia, USA.

Fuhrman, B., Roseblate, M., Hayek, T., Coleman, R. and Aviram, M. 2000. Ginger Extract consumption reduces plasma cholesterol, inhibits LDL Oxidation and attenuates development of Atherosclerosis in Atherosclerotic, Apolipoprotein E-Deficient Mice. Journal of Nutrition, 130: 11241131. 
Guyton, A. C., and Hall, J. E. 2006. Resistance of the body to infection: II. Immunity and allergy. In Guyton, A. C. and Hall, J. E. eds. Textbook of Medical Physiology. 11 th edition. Saunders Publishers, Philadelphia, PA. 440 pp. Google Scholar.

Hallagan, J. B., Allen, D. C., and Borzelleca, J. 1995. The Safety and Regulatory Status of Food, Drugs and Cosmetics, Colours Additives Exempt from Certification. Food Chemistry and Toxicology, 33 (6): 515-528.

Hosseini-Vashan, S. J., Golian, A. Yaghobfar, A. Zarban, A.Afzali, N. and Esmaeilinasab, P. 2012. Antioxidant status, immune system, blood metabolites and carcass characteristic of broiler chickens fed turmeric rhizome powder under heat stress. African Journal of Biotechnology, 11: 16118-16125.

Isroli, I., Yudiarti, T., Widiastuti, E. and Sugiharto, S. 2017. Effect of decocted turmeric on performance, hematological parameters and carcass traits of broiler chickens. Journal of Indonesian Tropical Animal Agriculture, 42(4):263$2 \quad 6 \quad 9$. http://ejournal.undip.ac.id/index.p hp/jitaa.

Jain, N. C. 1993. Essentials of veterinary haematology. Lea and Ferbeiger, Pennsylvania, PA.pp 7.

Kafi, A., Uddin, M. N., Uddin, M. J., Khan, M. M. H., and Haque,M. E. 2017.Effect of Dietary Supplementation of Turmeric (Curcuma longa), Ginger (Zingiberofficinale) and their Combination as Feed Additives on Feed Intake, Growth Performance and Economics of Broiler.
International Journal of Poultry

Science, 16(7): 257-265. doi:10.3923/ijps.2017.257.265

Kehinde, A. S., Obun, C. O., Inuwa, M. and Bobadoye, O. 2011. Growth performance, haematological and serum biochemical indices of cockerel chicks fed ginger (Zingiberofficinale) additive in diets. Animal Research International, 8(2): $1398-1404$.

Krames, A. 2010. Total Protein and A/G Ratio Tests. Mount Nittany Medical Center, 814:231-7000.

Lee, K. W., Lee, S. H., Lillehoj, H. S, Li, G. X., Jang, S. I., Babu, U. S., Park, M. S., Kim, D. K., Lillehoj, E. P., Neumann, A. P., Rehberger, T. G. and Siragusa, G. R. 2010. Effects of direct-fed microbials on growth performance, gut morphometry, and immune characteristics in broiler chickens. Poultry Science, 89:203-216. doi: 10.3382/ps.2009-00418.

Lentfer, T. L., Pendl, H., GebhardtHendrich, S. G., Trolich, E. K. and Von Borell, E. 2015. H/L ratio as a measurement of stress in laying hens - methodology and reliability. British Poultry Science, 56(2), 157163.

Menon, D. G., Bennett, D. C. Shaefer, A. M., and Chengm, K. M. 2013. Haematological and serum biochemical profile of farm emus (Dromaiusnovaehollandiae) at the onset of their breeding season. Poultry Science, 92:935-944.

Merck Manual. 2012.Haematologic reference ranges. Merck Veterinary Manual. Retrieved from http://www.merckmanuals.com/.

Murray, R. K., Granner, D. W., Mayes, P. A. and Rodwell, V. W. 2000. Harper's biochemistry. Applton and Lang. $25^{\text {th }}$ edition. 927 pp. Prentice 
Hall International, USA.

NRC (National Research Council). 1994. National Research Council. Nutrient Requirements of Poultry. 9th edition. National Academy Press, Washington, USA.

Onu, P. N. 2010. Evaluation of two herbal spices as feed additives for finisher broilers. Biotechnology in Animal Husbandry, 26 (5-6): 383-392. D O I : http://dx.doi.org/10.2298/BAH10 063830

Onyeyili, P. A., Egwu, G. O., Jibike, G. I., Pepple, D. J., and Ohaegbulam, J. O. 1992. Seasonal variation in haematological indices in the greybreasted guinea fow 1 (NumidamealagrisGallatapallas). Nigerian Journal of Animal Production, 18(2), 108-110. https://doi.org/10.51791/njap.v18i .2007

Patra, G., Ali, M. A., Chanu, K. V., Jonathan, L., Joy, L. K., Prava, N. Ravindran, R., Das, G. and Devi, L. I. 2010. PCR based d i a g n o s i s o f Eimeriatenellainfection in broiler chicken. International Journal of Poultry Science, 9 (8):813818. [Google Scholar]

Soetan, K. O., Akinrinde, A. S., and Ajibade, T. O. 2013. Preliminary studies on the haematological parameters of cockerels fed raw and processed guinea corn (Sorghum bicolour) (p. 49-52). Proceedings of 38th Annual Conference of Nigerian Society for Animal Production.

Sugiharto, I., Widiastuti, E., and Prabowo, N. S. 2011. Effect of turmeric extract on blood parameters, feed efficiency and abdominal fat content in broilers. Journal of Indonesian Tropical
Animal Agriculture, 36:21-26.

Ukoha, Q. A. and Onunkwo, D. N. 2016. The effects of turmeric (Curcuma longa) on the haematology and blood chemistry of broiler chickens. Sci-Afric Journal of Animal Science, 4:963-968.

Varbo, A., Benn, M., Tybjaerg-Hansen, A. and Nordestgaard, B. G. 2013. Elevated remnant cholesterol causes Ischemic heart disease without inflammation. Circulation, 128: 1298-1309.

Venkatesh, V., Sharma, J. D., and Kamal, R. 2002. A Comparative Study of Effect of Alcoholic Extracts of Sapindusemarginatus, Terminaliabelerica, Cuminumcyminumand Allium cepa on reproductive organs of male albino rats. Asian Journal of Experimental Sciences 16: 51-63.

Warnick, G.R., Benderson, J. and Albers, J. J. 1982. Dextran sulfate$\mathrm{Mg}^{2+}$ precipitation procedure for high-density-lipoprotein cholesterol. Clinical Chemistry, 28: 1379-1388.

WHO (World Health Organisation). 1987. Principles for the Safety Assessment of Food Additives and Contaminants in Food, Environmental Health Criteria, Vol. 174 p, 70. World Health Organization, Geneva

Williams, K., Ruotsalo, K., and Tant, M. S. 2021. Serum Biochemistry. Diagnosis Pet Services. https://vsahospitals.com/knowyour-pet/serum biochemistry\#. Accessed on 03-11-2021.

Received: $11^{\text {th }}$ August, 2021 Accepted: $10^{\text {th }}$ December, 2021 